\title{
Do Global Brands Benefit from a Unique Worldwide Image?
}

\author{
Isabelle Schuiling ${ }^{*}$, Jean-Jacques Lambin ${ }^{* *}$
}

\begin{abstract}
The trend towards increased globalisation had a major impact on the branding strategies of international companies.

Next to important economies of scale that a global brand can bring to the company, the advantage of benefiting from a unique worldwide image across markets is considered by managers as an important advantage to manage brands on a global basis.

Companies have traditionally followed two types of strategies to create their global brands. One strategy has consisted of expanding successful local brands on international markets. The second strategy has consisted of creating global brands from the start. These brands are launched on a worldwide basis quasi at the same time.
\end{abstract}

Keywords: Global Brand; Strategies for Global Brand; Worldwide Image; Country of Origin; Global Marketing; Global Markets

\section{Introduction}

The trend towards increased globalisation had a major impact on the branding strategies of international companies. In the past, international firms would develop brands that were adapted to the needs of local markets, under a multi-domestic marketing approach. They tend now to favour the development of global brands that ideally have the same product, the same name and the same positioning in all markets, under a global marketing approach.

$\square$ This is well illustrated by the example of Unilever that is at the end of the process of eliminating three quarter of its portfolio of brands to only keep 400 brands that have international presence or international potential.

\footnotetext{
*Full Professor of Marketing, Université Catholique de Louvain (isabelle.schuiling@uclouvain.be)

** Full Professor of Management, University of Milan-Bicocca (jean-jacques.lambin@ unimib.it) 
Many reasons can explain the acceleration of global brand development. Next to important economies of scale that a global brand can bring to the company, the advantage of benefiting from a unique worldwide image across markets is considered by managers as an important advantage to manage brands on a global basis.

The objective of this article is to question whether these global brands do really benefit from a unique image in all markets. Many global brands have been first strong local brands in their country of origin before being expanded in the rest of the world. Are their image different in their country of origin versus other countries? For example, is the Mercedes brand image the same in Germany than in other countries? Is the image of Barilla pasta similar in Italy than in the rest of the world? And what about Godiva perception in Belgium versus other countries?

Some recent research has evaluated whether the fact of being global could influence brand purchase (Steenkamp, Batra and Alden 2003, Holt, Quelch and Taylor 2003, Alden, Steenkamp and Batra 1999) but no research has been conducted so far to understand if global brands really benefit from a unique global image everywhere and whether this image is different in the country of origin versus the rest of the world.

In this article, we will first establish what the strategies of international companies are in the development of global brands, second, we will review the impact of the country of origin on the perception of brands and third, we will evaluate, via an exploratory testing, what their images are in different countries.

\section{Strategies for Global Brand Creation}

International companies have traditionally followed two types of strategies to create their global brands. One strategy has consisted of expanding successful local brands on international markets. This strategy has been followed over decades by many multinational firms.

$\square$ For example, a brand like 'Evian' was first a successful local brand
in France before it was expanded on a worldwide basis. Evian has now
become the leading global brand in the worldwide mineral water
market. This is also the case of Barilla that was initially a strong local
brand in Italy and is now the successful worldwide leading pasta brand
that we all know. Nivea from Beiersdorf in Germany was also first a
successful local brand before becoming the European cosmetic leader.
Even Coca-Cola is part of this first group of brands.

The advantages of this first strategy is to build on a winning local brand proposition and increase the chances of success. It also permits to build progressively a brand on a global basis that is less risky and less expensive for the company. If the expansion is not successful, the financial losses will be limited.

The second strategy has consisted of creating global brands from the start. These brands are launched on a worldwide basis quasi at the same time. This is the most recent strategy adopted by certain multinationals such as Procter and Gamble. The creation of global brands such as Pringles, Swiffer or Kangoo are good examples of this strategy. The key advantage is to rapidly build a world brand with the same 
name and positioning in every market and benefit from substantial economies of scale. The risk is of course to invest massively on a worldwide basis without being sure of a worldwide success.

The majority of existing global brands have been created following the first strategy. These brands were first strong local brands in their home country before being expanded internationally. Only a few number of most recent global brands have been global as from the start. Most global brands have therefore a country of origin. In this article, the analysis will focus on this group of brands.

\section{The Advantage of Benefiting from a Worldwide Image}

The advantages of moving to global marketing have been discussed for many years in the marketing literature (Buzzell 1968, Levitt 1983, Jain 1989, Boddewijn, Soelh and Picard 1986, Huszagh, Fox and Day 1986, Quelch and Hoff 1986 Douglas and Wind 1987, Craig and Douglas 2000).

The advantages of building global brands are well known. The most important one is the possibility to benefit from large economies of scale. These economies of scale can be generated in all parts of the business system. The concentration of $\mathrm{R} \& \mathrm{D}$ efforts in few international locations, the rationalisation of the manufacturing process and the standardisation of the marketing program lead to very large economies of scale that generate important cost reductions. The latter improves significantly the company financial performance.

The second advantage that has often been highlighted is the creation of a unique worldwide image. This brings worldwide coherence in the brand image, enables the company to develop one advertising campaign and leverages the use of international media. This also leads to substantial reduced costs in the communication area. The key question of this article is to review whether global brands really benefit from this advantage.

\section{Influence from the Country of Origin of Global Brands}

We know from research that the country of origin has an impact on product perception. Many studies have been conducted in this area (COO research) and they show that the country of origin of the products had an impact on consumer's evaluation of these products (Schooler 1971, Han and Terpstra 1988, Hong and Wyer 1989, Samiee 1994). The studies have indicated that consumers have a tendency to better evaluate local products than foreign products (Nagashima 1977, Kaynak and Cavusgil 1983, Han 1989, Bilkey and Nes 1982, Schooler 1971, Sharma and Shimp 1995), although that this bias varied across consumer segments and countries (Heslop and Papadopoulos 1993, Shimp and Sharma 1987).

Recently, some authors have shown that brands perceived as coming from a non local country of origin, especially from Western countries were preferred to brands seen as local and that was not only linked to perceived quality but also to social status (Batra, Alden and Steenkamp 2000).

No work has however been done to identify whether the country of origin of global brands has an impact on their image. Recent studies on global brands evaluate whether the fact of being global could be an advantage for consumers. 
Some have indicated that perceived brand globalness (PBG) could create perception of brand superiority (Shocker, Srivastava and Ruekert 1994, Kapferer 1992) and perception of brand prestige. Some others have highlighted the fact that global brands could also connote cosmopolitan, sophistication and modernism (Friedman 1990). Other authors have also tested whether factors such as status, country, quality, citizenship or American values (Holt, Quelch and Taylor 2003) would influence the preference for global brands. No work has been developed to evaluate whether the image of global brands is similar in their country of origin versus the rest of the world.

We consider that global brands might benefit from a stronger image in their country of origin. As they were initially strong local brands, they might benefit from the characteristics of local brands. Recent research on local brands (Kapferer and Schuiling 2003) has shown that local brands benefit from a better image that international brands on key brand equity elements. In particular, consumers evaluate local brands as much more trustworthy than international brands.

\section{Exploratory Testing}

To better understand global brand images, we have conducted an exploratory research on a selection of global brands from the large international data base from Young and Rubicam (known as the Brand Asset Valuator). These global brands have been selected from a sample of 347 global brands and 9739 people interviewed in 1999-2000 covering twelve product categories in the food sector (a list is provided in attachment 1). It included the four largest European countries UK, Germany, France and Italy. For each brand, 48 image attributes were available to consumers to evaluate brands. We will focus our analysis on the attributes most often used by people to evaluate these brands. These image attributes were (by order of importance) : 'High quality', 'trustworthy', 'good value', 'simple', 'down to earth', 'friendly' and 'traditional'.

This exploratory research showed that the image of global brands was very different in their country of origin versus other countries where they were also present.

Table 1: Image Attributes of Global Brands

\begin{tabular}{|l|c|c|}
\hline $\begin{array}{c}\text { Attributes } \\
(\%)\end{array}$ & $\begin{array}{c}\text { Global brands in their country } \\
\text { of origin } \\
(\mathrm{N}=58) \\
(\mathrm{a})\end{array}$ & $\begin{array}{c}\text { Global brands in } \\
\text { other countries } \\
(\mathrm{N}=289) \\
(\mathrm{b})\end{array}$ \\
\hline High quality & 31.2 & $24.3 *$ \\
Trustworthy & 29.3 & $17.9 *$ \\
Good value & 19.9 & $16.8 *$ \\
Simple & 19.1 & 17.2 \\
Down to earth & 18.8 & $14.7 *$ \\
Friendly & 13.8 & 14.4 \\
Traditional & 20.5 & $12.7 *$ \\
\hline
\end{tabular}

* Statistically different (a) versus (b) at $\mathrm{p}<0.05$ and $\mathrm{N}=$ Number of Brands. 
As indicated in Table 1, global brands benefit in their country of origin from a better image on key brand image attributes. They are perceived as delivering better quality and generating more trust than global brands in other countries. Their image is also stronger on the attributes of good value and down to earth. They are also seen as more traditional, that is quite logical as they have been first strong local brands in their home country.

Interestingly, the analysis also shows, as indicated in table 2, that global brands benefit from a significantly higher level of awareness in their country of origin $(86 \%)$ versus other countries $(73 \%)$. They even also enjoy a higher usage level in their home country (48\%) versus other countries (37\%).

Table 2: Awarness and Usage Levels of Global Brands

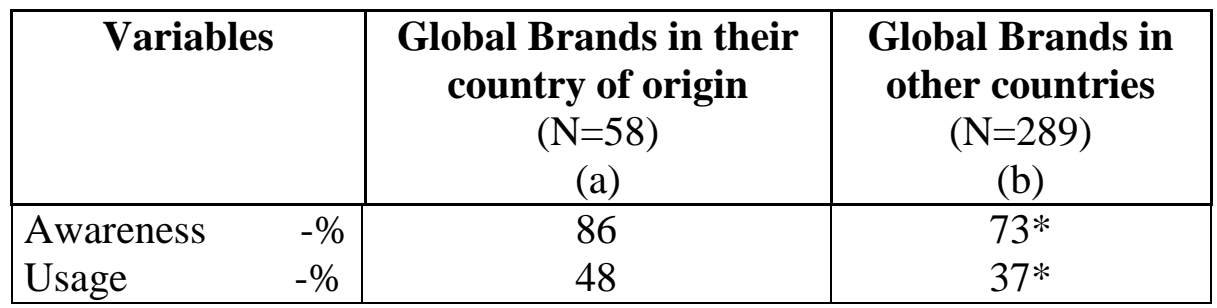

* Statistically different (a) versus (b) at $\mathrm{p}<0.05$ and $\mathrm{N}=$ Number of Brands.

This confirms the strength of global brands in the countries where they have first been created versus other markets where they have been later expanded.

We will also illustrate these findings by taking two specific examples of very known global brands: Evian and Barilla.

If we compare Evian in its country of origin, France, versus other countries covered in the database, we find that the image of Evian is stronger in France on key attributes such as 'high quality', 'trustworthy', 'good value', 'down to earth', 'simple' and 'traditional' versus Italy, UK and Germany, as indicated in table 3.

Table 3: Evian Key Image Attributes in Country of Origin Versus other Countries

\begin{tabular}{|l|c|c|c|c|}
\hline $\begin{array}{c}\text { Key image } \\
\text { attributes }\end{array}$ & $\begin{array}{c}\text { France= } \\
\text { Country of } \\
\text { origin }\end{array}$ & Germany & Italy & UK \\
\hline High quality & 46.6 & $22.3 *$ & $13.6 *$ & $28.6 *$ \\
Trustworthy & 55.5 & $10.6 *$ & $31.0 *$ & $16.6 *$ \\
Good value & 19.5 & $10.3 *$ & $8.9 *$ & 20.4 \\
Simple & 30.8 & $14.7 *$ & $24.0 *$ & $20.6 *$ \\
Down to & 25.8 & $10.3 *$ & $15.5 *$ & $19.2 *$ \\
earth & & & & \\
Friendly & 14.0 & 12.7 & $5.8 *$ & $9.4 *$ \\
Traditional & 23.4 & $7.9 *$ & $6.2 *$ & $13.4 *$ \\
\hline
\end{tabular}

* Statistically different (a) versus (b), (c) and(d) at $\mathrm{p}<0.05$. 
The situation is similar for Barilla in Italy versus other European countries, as shown in table 4. The attributes of 'trustworthy', 'good value', 'down to earth', 'traditional' are rated at a significantly higher level in Italy versus other countries. Interestingly, Barilla is the only brand tested for which the attribute of 'high quality' is lower in its country of origin versus other countries. We explain this by the fact that for Italians, Barilla is an industrial pasta and as such can not been rated high on 'quality' versus fresh pasta. In other countries, however, Barilla is viewed as 'the' reference in Italian pasta.

Table 4: Barilla Image Attributes in Country of Origin Versus other Countries

\begin{tabular}{|l|c|c|c|}
\hline Key brand attributes & France & Germany & $\begin{array}{c}\text { Italy = } \\
\text { Country of } \\
\text { origin } \\
\text { (c) }\end{array}$ \\
\hline High quality & (a) & (b) & 34.9 \\
Trustworthy & $56.9 *$ & 40.6 & 56.6 \\
Good value & $44.8 *$ & $17.4 *$ & 33.8 \\
Simple & $26.8 *$ & $17.2 *$ & 17.8 \\
Down to earth & $26.8 *$ & 18.1 & 35.9 \\
Friendly & $16.0 *$ & $10.6 *$ & 13.7 \\
Traditional & 14.1 & 16.6 & 34.6 \\
\hline
\end{tabular}

* Statistically different (c) versus (a) and(b) at $\mathrm{p}<0.05$;UK data not available.

This first attempt to better understand global brand images confirms that the country of origin has an impact on the brand image. This might be linked to the fact that these global brands have been first strong local brands in their home country. Consumers have often known them for many years and have developed a close relationship with them. This indicates that we need to operate a distinction when we manage global brands on a worldwide basis.

\section{Conclusion}

The advantages of building global brands are not only to benefit from substantial reduction of costs but also to create a unique worldwide image.

We have seen that most existing global brands have been created by the internationalisation of a strong local brand. As such, they have a clear country of origin.

The objective of this article was to evaluate if global brands benefited from a similar image in every country where they were present. The research, based on an exploratory analysis of the Young and Rubicam data base (known as the Brand Asset Valuator), indicated that there was an important difference in the image of global brands in their country of origin versus other countries. The image was much stronger on key brand equity attributes that were most often used by consumers to evaluate brands. The difference was significant on attributes such as 'high quality', 'trustworthy', 'good value', 'down to earth' and 'traditional'. The analysis also showed that these global brands enjoyed a significant higher level of 
awareness and usage. This confirmed the strengths of global brands in their home countries versus other countries.

We can therefore not consider that the brand image of global brands are unique or even similar in all markets. A clear distinction has to be established between the image of global brands in their country of origin and in other countries where they have been expanded later on.

These findings also have important managerial implications.

First, the key question is to evaluate how the global brand has been positioned over the years in different international markets because different images might also be linked to different positioning. A brand like Godiva was initially not positioned the same way in its home country Belgium versus other countries. In Japan and the United States, the brand was positioned on a more exclusive basis. This is also the case of brands such as Benetton and Zara that were positioned slightly differently in their home country than in the rest of the world.

Second, it indicates that an advertising campaign that works well in the country of origin might therefore not work well in other markets. There is often a tendency to use advertising that is 'proven successful' in the home country for the other countries. In view of the different images identified, there is a need to validate thoroughly via testing the use of the home country advertising.

Third, the results show the need to regularly monitor brand images in key countries where the global brand exist and not assume that the country of origin information is sufficient. In the current context of globalisation, there is a trend to reduce local market research in order to decrease costs. Research is, however, key before deciding any important branding changes in key markets outside the country of origin.

In net, this shows that the analysis of global brands should be contrasted depending on the country of origin, even if these brands have been present on international markets for many years.

For further research, it will be interesting to confirm these results by analysing global brands indifferent sectors such as in durable goods, high tech or luxury goods. 


\section{Attachments}

\section{Types of Product Category}

\begin{tabular}{|l|}
\hline Product Category \\
\hline Alcohol \\
Chocolate \\
Beer \\
Yoghurt \\
Mineral water \\
Frozen goods \\
Chewing gum \\
Fruit juice \\
Coffee \\
Ice cream \\
Soup \\
Pasta \\
\hline
\end{tabular}

\section{Brands Selected}

\begin{tabular}{|l|l|}
\hline Countries & Brands \\
\hline France & $\begin{array}{l}\text { Evian } \\
\text { Kronenbourg } \\
\text { Danone }\end{array}$ \\
\hline Italy & $\begin{array}{l}\text { Barilla } \\
\text { Cinzano }\end{array}$ \\
\hline UK & $\begin{array}{l}\text { Kit-Kat } \\
\text { Guiness } \\
\text { Gordon's Gin }\end{array}$ \\
\hline Germany & $\begin{array}{l}\text { Lowenbrau } \\
\text { Mueller }\end{array}$ \\
\hline
\end{tabular}

\section{Bibliography}

Alden D.L., Steenkamp J-B., Batra R., Brand Positioning through Advertising in Asia, North America and Europe: The Role of Global Consumer Culture, Journal of Marketing, vol. 63, 1999, pp. 75-87.

http://dx.doi.org/10.2307/1252002

Batra R., Ramaswamy V., Alden D., Steenkamp, J-B., Ramachander, S., Effects of Brand Local and Non Local Origin on Consumer Attitudes in Developing Countries, Journal of Consumer Psychology, n. 9, 2000, pp. 83-95. http://dx.doi.org/10.1207/S15327663JCP0902_3

Bilkey W.J., Nes E., Country of Origin Effects on Product Evaluation, Journal of International Business Studies, vol. 8, n. 1, 1982, pp. 89-99.

http://dx.doi.org/10.1057/palgrave.jibs.8490539 
Boddewyn J.J., Soehl R., Picard J., Standardisation in International Marketing: Is Ted Levitt in Fact Right?, Business Horizons, November-December, 1986, pp. 68-75.

http://dx.doi.org/10.1016/0007-6813(86)90040-6

Brondoni S.M., Brand Policy and Brand Equity, Symphonya Emerging Issues in Management (symphonya.unimib.it), n.1, 2000/2001. http://dx.doi.org/10.4468/2001.1.02brondoni

Buzzel R.D., Can You Standardise Multinational Marketing?, Harvard Business Review, NovemberDecember, 1968, pp. 102-113.

Friedman, J., Being in the World: Globalisation and Localisation, Theory, Culture and Society, n. 7, 1990, pp. 311-328.

http://dx.doi.org/10.1177/026327690007002018

Han C.M., Country Image: Halo or Summary Construct?, Journal of Marketing Research, vol. 26, May, 1989, pp. 222-229. http://dx.doi.org/10.2307/3172608

Han C.M., Terpstra V., Country of Origin Effects for Uni-National and Bi-National Products, Journal of International Business Studies, vol. 19, Summer, 1988, pp. 235-255. http://dx.doi.org/10.1057/palgrave.jibs.8490379

Heslop L.A., Papadopoulos N., But Who Knows Where or When Reflections on the Images of Countries and Their Products, N. Papadopoulos, L. Heslop (ed.), Product-Country Images: Impact and Role in International Marketing, New York, International Business Press (Haworth), 1993, pp. 39-75.

Holt D., Quelch J., Taylor E., Managing the Transnational Brand: How Global Perceptions Drive Value, Unpublished Working Paper, Harvard Business School, 2003.

Hong Sung-Tai, Wyer Robert S., Effects of Country-of-Origin and Product-Attribute Information Processing Perspective, Journal of Consumer Research, vol. 16, 1989, pp. 175-187. http://dx.doi.org/10.1086/209206

Huszagh S., Fox R.J., Day E., Global Marketing: An Empirical Investigation, Columbia Journal of World Business, n. 21, 1986, pp. 31-44. http://dx.doi.org/10.1002/tie.5060280302

Jain S.C., Standardisation of International Marketing Strategy: Some Research Hypothesis, Journal of Marketing, vol. 53, January, 1989, pp. 70-79. http://dx.doi.org/10.2307/1251525

Kapferer J-N, EUROCOM, How Global are Global Brands?, ESOMAR Conference proceedings: The challenge of Branding, 1992, pp. 199-215.

Kapferer J.N., Schuiling I., How Unique are Local Brands? An Empirical Comparison of Local and International Brands in the Food Industry, Unpublished Working Paper, University of Louvain, Institut d'Administration et de Gestion, 2003.

Kaynak E., Cavusgil S.T., Consumer Attitudes Towards Products of Foreign Origin: Do They Vary Across Product Classes, in International Journal of Advertising, vol. 2, 1983, pp. 147-157.

Lambin J.J., Market-Driven Management, Strategic and Operational Marketing, Palgrave, 2000.

Levitt T., The Globalisation of Markets, Harvard Business Review, vol. 61, May-June, 1983, pp. $92-$ 108.

Nagashima A., A Comparative 'Made in' Product Image Survey among Japanese Businessmen, Journal of Marketing, vol. 41, 1977, pp.95-100. http://dx.doi.org/10.2307/1250943

Samiee S., Customer Evaluation of Products in a Global Market, Journal of International Business Studies, 3rd quarter, 1994, pp. 579-604. http://dx.doi.org/10.1057/palgrave.jibs.8490213

Shocker A.D., Srivastava R.K., Ruekert R.W., Challenges and Opportunities Facing Brand Management: An Introduction to the Special Issue, Journal of Marketing Research, n. 31, 1994, pp. 149-158.

http://dx.doi.org/10.2307/3152190 
Schooler R., Bias Phenomena Attendant to the Marketing of Foreign Goods in the US, Journal of International Business Studies, vol. 2, n. 1, 1971, pp. 71-81.

http://dx.doi.org/10.1057/palgrave.jibs.8490732

Shimp T.A., Sharma S., Consumer Ethnocentrism: Construction and Validation of the CETSCALE, Journal of Marketing Research, n. 24, 1987, pp. 280-289. http://dx.doi.org/10.2307/3151638

Steenkamp J-B., Batra R., Alden D.L., How Perceived Globalness Creates Brand Value, Journal of International Business Studies, n. 34, 2003, pp. 53-65.

http://dx.doi.org/10.1057/palgrave.jibs.8400002 